relation to the weight of the animals, as it tended to be after hypophysectomy $(1 \cdot 12 \mathrm{u} . / 100 \mathrm{gm}$. in 41 rats 3-4 weeks after the subcutaneous implantation of two $15 \mathrm{mgm}$. tablets of stilbœestrol, and 1.01 u./100 gm. one month after implantation of one $12 \mathrm{mgm}$. tablet of cestrone). When rats carrying stilbœstrol tablets further received injections of crude anterior pituitary extract, the insulin increased in approximate proportion to the growing body-weight, remaining higher than in control rats $(1.26 \mathrm{u} . / 100 \mathrm{gm}$. for 42 rats after two weeks daily treatment with extract).

In order to demonstrate that the pituitary gland secretes a pancreotropic hormone, it is necessary to show that removal of the gland results in a diminution in size and activity of the pancreatic islets (in proportion to the body weight) and that this condition may be cured or prevented by pituitary therapy. The evidence here presented does not support the assumption that the anterior pituitary lobe exerts a direct hormonic control over the islets of Langerhans, although extracts of this gland contain a pancreotropic substance capable of increasing the amount of islet tissue and of insulin, in the pancreas of the normal rat $^{3,4}$.

The results will be given in detail and discussed in a paper to be published by one of us (M. G.) in the Journal of Endocrinoloay. We wish to express our indebtedness to Messrs. Boots and Co. for the gift of stilbœstrol and for the preparation of the tablets.

M. GRIFFITHS.

(Overseas Scholar of the 1851 Commission) F. G. Young.

National Institute for Medical Research,

Hampstead,

London, N.W.3.

1 Krichesky, B., Proc. Soc. Exp. Biol., N.Y., 34, 126 (1936).

Haist, R. E., and Best, C. H., Science, 91, 410 (1940).

3 Richardson, K. C., and Young, F. G., J. Physiol., 91, 352 (1937).

4 Marks, H. P., and Young, F. G., Lancet, i, 493 (1940).

\section{Nature of Oxidative Phosphorylation in Brain Tissue}

A connexion between oxidation of pyruvic acid and esterification of inorganic phosphate with hexosemonophosphate to hexosediphosphate in brain preparations has been recently described ${ }^{1}$. I have now found that glucose can be substituted for hexosemonophosphate and the phosphorylation product is still hexosediphosphate. The necessity of 'adenine nucleotide' for the above reaction as well as the dependence of the oxidation on the presence of both 'adenine nucleotide' and inorganic phosphate ${ }^{2}$ led to the assumption that the oxidation of pyruvic acid was linked up to a phosphorylation of adenylic acid to adenosinepolyphosphate, which would then transfer its labile phosphate groups to hexosemonophosphate or glucose. This is supported by the fact that either glucose or hexosemonophosphate can be phosphorylated to hexosediphosphate anærobically by transfer of phosphate from phosphopyruvic acid in the presence, but not in the absence, of adenylic acid. Half of the phosphopyruvate phosphate is set free and the other half is esterified with glucose or hexosemonophosphate. This is the same ratio as was found by Ostern, Guthke and Terszakovec ${ }^{3}$ for the transfer of phosphate from adenosinetriphosphate to hexose- monophosphate in muscle extract. The phosphorylation of glucose under these conditions had not been so far observed in animal tissues.

The reactions taking place with glucose can be formulated as follows :

(1) 4 phosphopyruvic acid +2 adenylic acid $=2$ adenosinetriphosphate +4 pyruvic acid.

(2) 2 adenosinetriphosphate +1 glucose $+2 \mathrm{H}_{2} \mathrm{O}=1$ hexosediphosphate $+2 \mathrm{H}_{8} \mathrm{PO}_{4}+2$ adenylic acid.

The sum of equations (1) and (2) is the overall reaction (3):

(3) 4 phosphopyruvic acid +1 glucose $+2 \mathrm{H}_{2} \mathrm{O}=1$ hexosediphosphate $+2 \mathrm{H}_{3} \mathrm{PO}_{4}+4$ pyruvic acid.

Recently Colowick, Welch and Cori* concluded that the oxidative phosphorylation of glucose in kidney extracts, previously studied by Kalckar ${ }^{5}$, is linked up with the oxidation of succinic to fumaric acid. In brain dispersions oxidation of succinate does give rise to phosphorylation of glucose. However, if oxidation of the pyruvate-arising by subsequent oxidation of malate to oxaloacetate and breakdown of the latter-is checked by arsenite, the ratio atoms phosphorus esterified to molecules oxygen taken up is only about a half of that obtained when pyruvate is oxidized (in the absence of arsenite) as shown in the accompanying table. Arsenite, whilst fully inhibiting both oxidation of pyruvate and the accompanying phosphorylation, is without effect on the phosphorylation of glucose by transfer of phosphate from phosphopyruvic acid.

1.5 ml. dispersion from pigeon brain (dialysed 6.5 hours) to $2 \cdot 3$ ml. with additions including phosphate buffer $p \mathbf{H} 7 \cdot 3(0 \cdot 025 M)$, $\mathrm{Mg}++(0.2 \mathrm{mgm})$, adenylic acid $(0.0007 \mathrm{M})$, glucose $(10 \mathrm{mgm}$. and $\mathrm{NaF}(0.02 \mathrm{M})$. $35 \mathrm{~min}$. in air at $38^{\circ}$. (O, uptake measured during the last $30 \mathrm{~min}$.).

\begin{tabular}{|c|c|c|c|c|c|}
\hline & \multirow{2}{*}{$\begin{array}{c}\text { No } \\
\text { further } \\
\text { addition }\end{array}$} & \multicolumn{2}{|c|}{$\begin{array}{c}\text { Na fumarate } \\
(0.005 M) \\
+ \text { Na pyruvate } \\
(0.013 M)\end{array}$} & \multicolumn{2}{|c|}{$\begin{array}{l}\text { Na succinate } \\
(0.03 M)\end{array}$} \\
\hline & & $\underset{\text { arsenite }}{\text { No }}$ & $\begin{array}{c}0 \cdot 008 M \\
\text { Na } \\
\text { arsenite }\end{array}$ & $\begin{array}{c}\text { No } \\
\text { arsenite }\end{array}$ & $\begin{array}{c}0.008 M \\
\text { Na } \\
\text { arsenite }\end{array}$ \\
\hline $\begin{array}{l}\mu \mathrm{l} \mathrm{O}_{2} \text { uptake } \\
\text { mgm. P esterifled } \\
\text { atoms } \mathbf{P} / \text { mols } O_{2}\end{array}$ & $\underline{0}$ & $\begin{array}{l}320 \\
1 \cdot 20 \\
2 \cdot 78\end{array}$ & $\begin{array}{c}19 \\
0 \cdot 00 \\
0 \cdot 00\end{array}$ & $\begin{array}{l}276 \\
0 \cdot 77 \\
2 \cdot 01\end{array}$ & $\begin{array}{l}178 \\
0 \cdot 23 \\
0.94\end{array}$ \\
\hline
\end{tabular}

The above suggests that the oxidative phosphorylation may be of a twofold nature; half of it being connected with the dehydrogenation of pyruvic acid as suggested previously ${ }^{1}$, the other half with the transfer of hydrogen catalysed by dicarboxylic acids. This view would seem to be supported by the fact that when pyruvate is oxidized by brain dispersions, in the presence of fumarate, the $\mathrm{P} / \mathrm{O}_{2}$ ratio in the first few minutes is 4 atoms phosphorus to 1 molecule oxygen. It would be difficult to understand how the removal of $2 \mathrm{H}$ would give rise to an uptake higher than 1 atom phosphorus unless their further catalytic transfer is also linked up with phosphorylation.

I am indebted to Prof. R. A. Peters for his interest and to the Nuffield Trustees and the Rockefeller Foundation for grants in aid of this work.

Department of Biochemistry,

S. OCHOA.

Oxford.

August 5.

1 Ochoa, Nature, 145, 747 (1940).

- Banga, Ochoa and Peters, Biochem. J., 33, 1980 (1939).

${ }^{3} Z$. physiol. Chem., 243, 9 (1936).

- J. Biol. Chem., 183, 359 and 641 (1940).

s Biochem. J.. 33, 631 (1939). 